\title{
The Application of the Law in International Commercial Arbitration
}

\section{Dzyuba Lyubov Mikhailovna ${ }^{1}$, Fedorenko Nataliia Vladimirovna ${ }^{2}$, Fedorova Viktoriya Vladimirovna ${ }^{3}$}

Abstract:

This paper focuses on the application of the law in international commercial arbitration applicable to the merits and prospects of its resolution, considering foreign and national experience.

The article analyzes the expression of will of subjects of law through the prism of the reservation.

Keywords: Law, international private law, international commercial arbitration, arbitration clause, arbitration court, arbitrator, international commercial activities, private law disputes.

\footnotetext{
${ }^{1}$ Senior Lecturer of Civil Law, Rostov State University (RINH) dzuba017@mail.ru

${ }^{2}$ D. SOC.N., Professor, Head of the Civil Procedure Department of the Law Faculty of Rostov State University (RINH) fedorenko_vladim@mail.ru

${ }^{3}$ Senior Lecturer of Civil Law, Law Faculty of Rostov State University (RINH)
} 


\section{Introduction}

International commercial arbitration (ICA) is a non-state commercial arbitration court specifically designed to deal with disputes between parties of international commercial transactions, parties consisting by persons of different nationalities (foreign firms and organizations). These bodies should also be distinguished from another type of arbitration court, which can hear disputes between the states - the subjects of public international law. ${ }^{4}$

This article dwells on the hypothesis of the inevitable development of international commercial arbitration, as well as inevitability of the appearance of the specificity, which is due to the peculiarities of law-enforcement practice. The authors of this article aim to verify this hypothesis, and to define the terms for international commercial arbitration and law enforcement.

\section{Literature review}

In the Russian legal literature description of the various theories of the legal nature of arbitration developed by famous scientists as F. Merlin, Lena Bernard and Pile on the root of the J. Foyer. Jurist, A.I. Minakov proposed a classification of elements of the arbitration agreement on a substantive law. ${ }^{5}$ S.N. Lebedev gave a theoretical justification of the principle of competence, i.e. the law of arbitration to make a decision about its authority to consider a particular case, and the autonomy of the arbitration agreement. ${ }^{6}$ I.O. Khlestova conducted a comprehensive study of the operation of the ICA in the foreign economic relations of the countries-members of CMEA and the application of the principle of compulsory jurisdiction of disputes to arbitration based on the rules of the international Treaty. ${ }^{7}$ The Italian scientist G. Kordero-Moss identified the appearance of certain marks of arbitration delocalization, resulting in the possibility to hold arbitration under third state law, and the necessity to revise existing international instruments. ${ }^{8}$

\section{Object, subject and methods of research}

\footnotetext{
${ }^{4}$ Getman-Pavlova I. V. private International law: Textbook. - Moscow: Publishing house Eksmo, 2005. - S. 544-546.

${ }^{5}$ Minakov A. I.:Arbitration agreements and the practice of consideration of foreign economic disputes. And:The Faculty Of Law. lit.Moscow. P. 144.1985.

${ }^{6}$ Lebedev S. N.: International commercial arbitration. And: Intern. Relationship. Moscow. S. 219.1965 .

${ }^{7}$ Khlestova acting Arbitration in foreign trade relations of member countries of the CMEA. M.: Nauka, 1980. - 160 p.

${ }^{8}$ Cordero Moss, A Sight To Behold. The autonomy of the will in the practice of international commercial arbitration: /// Guitarcross; Under the editorship of A. A. Rubanov; ROS. Acad. Sciences, Institute of state and law, «Norsk hydro». S. - M. : ihip, 1996. - 84 p.; 22 cm; ISBN 5-201-01323-6 : B. TS. The international arbitration.
} 
The object of research - legal relations of the parties to the arbitration proceedings arises from the resolution of foreign trade and economic disputes. The subject of research is the legal analysis of international treaties, the legal nature and application of law in ICA.

In the study of object and subject, the authors applied to the professional literature on ICA, addressed to the international public, international private law, civil and arbitration process. The research methods used in the present work is dialectical, systemic, comparative legal, logical and qualitative.

\section{Results and discussion}

\subsection{The legal nature of international commercial arbitration}

Any concept included in the theoretical model, the validity of which is indispensable must be analyzed in terms of validity in national and international level. Theoretical analysis is always based on the study of those phenomena that form a general idea about the object of the study. In the present work, the authors conducted a study of aspects of international commercial arbitration.

The question arises, what is the general nature of international commercial arbitration. In various fields of scientific knowledge, the answer to this question is allowed depending on copyright items. Any management activity involves not only the choice of one of several options for the development of manageable processes to bring the system to any proper condition, but also the framework boundaries within which this choice is made. It is difficult to imagine a situation in modern society where the choice of whether a person establishes obligatory rules of conduct. The choice of strong and imperious action is always subjective. Rules as formalized tribute always objective. Their objectivity is based on the fact that the will, which is the basis of creating rules, reflect the tribute as it is understood in society at a certain stage of historical development.

After analyzing the legal nature of arbitration and comparing opinions expressed by scientists we can distinguish at least three different concepts:

1) Contract concept of the legal nature of arbitration based on the arbitration agreement, consisting in the submission of a dispute for settlement to the arbitration which represents an ordinary civil contract. The subject of this contract is the party to choose the type of arbitration, the time and place of arbitration, the determination of the procedure of arbitration and the substantive law to be applied by the arbitrators. ${ }^{9}$

\footnotetext{
${ }^{9}$ Nikolyukin S. V. international civil procedure and international commercial arbitration: a textbook/S. V. Nikolyukin. - Moscow: LEGAL, 2017.
} 
2) Procedural concept, argues that arbitration is a special form of justice, which is exercised on behalf of the state. Arbitration agreement is an agreement of a procedural nature, the purpose of which is the exclusion of the jurisdiction of the state court.

3) Combined concept of considering the arbitration includes substantive and procedural legal elements, provides the use of not only the private law of the state where the arbitration takes place, but the relevant foreign law.

The main sources of law governing international commercial arbitration, are international treaties and domestic legislation. ${ }^{10}$ These include:

$\checkmark$ The New York Convention 1958 on the recognition and enforcement of foreign arbitral awards, a universal character of which the number of participants in more than 120 countries;

$\checkmark$ The European Convention 1961 on international commercial arbitration, commonly known in the Russian legal literature as the European Convention on international commercial arbitration;

$\checkmark$ The European Convention 1966, providing a Uniform law on arbitration adopted and operating under the Council of Europe. The Council of Europe is an international organization of regional character, whose purpose is the promotion of cooperation of European States in the economic, political, legal and cultural fields. Russia became a member of the Council of Europe in 1996; currently the number of members of this authoritative international organization is more than 40 States;

$\checkmark$ The Inter-American Convention 1975 on international commercial arbitration, acting in a large group of Latin American States, and a number of other conventions.

In Russia currently exists and is in force the Law of the Russian Federation «On international commercial arbitration» of 7 July 1993 The Law was developed in accordance with the basic provisions of the UNCITRAL Model law 1985, which is directly emphasized in its preamble. In this connection it is necessary to emphasize the role of normative documents of non-legal nature in the system of sources of law governing international commercial arbitration. ${ }^{11}$

An important argument of the legal nature of arbitration and its differences from state court is its non-governmental nature. Arbitration is the arbitral tribunal competent to adjudicate only in the case of an arbitration agreement between the disputing parties, i.e. in case of explicit consent of both parties.

\footnotetext{
${ }^{10}$ Musin V. A., Skvortsov O. Y.: international commercial arbitration: a Textbook. And: Infotropic Media. Moscow. From:496.2012

${ }^{11}$ Karabelnikov B. R. international commercial arbitration. Tutorial. - M.: Moscow school of social and economic Sciences, 2013. - 541 p.
} 
The Court is an organ of the judicial system of the state, confers competence in the power of legislation, in virtue of Express provision of national law and not by virtue of the agreement of the parties. ${ }^{12}$ From the foregoing it must be concluded that the state court and arbitration are separate jurisdictional authorities having different legal nature.

In practice this distinction is that in the course of the arbitral proceedings they can resolved a number of issues with the participation of the state court using its powers. In Table 1 the advantages and the disadvantages of different aspects of arbitration are presented:

Table 1. Advantages and Disadvantages of arbitration

\begin{tabular}{|c|c|c|}
\hline Aspect & Advantages & Disadvantages \\
\hline $\begin{array}{l}\text { The enforceability } \\
\text { of a future } \\
\text { judgment against } \\
\text { the other side of } \\
\text { things }\end{array}$ & $\begin{array}{l}\text { international arbitral award } \\
\text { enforced worldwide under the } \\
\text { New York Convention on the } \\
\text { recognition and enforcement of } \\
\text { foreign arbitral awards. }\end{array}$ & $\begin{array}{l}\text { in the event of winning in state } \\
\text { court to execute its decision in } \\
\text { other States will be possible only } \\
\text { under a special international } \\
\text { agreement or on the basis of } \\
\text { mutual consent. }\end{array}$ \\
\hline Privacy & $\begin{array}{l}\text { arbitration proceedings is more } \\
\text { closed and, if desired by both } \\
\text { Parties may remain } \\
\text { confidential for a long time. As } \\
\text { a rule, except when the court } \\
\text { makes a decision on a closed } \\
\text { session or otherwise restricts } \\
\text { the publicity of the case, court } \\
\text { proceedings can be known to } \\
\text { the General public and the } \\
\text { press, and judicial decisions } \\
\text { may be published. }{ }^{13}\end{array}$ & $\begin{array}{l}\text { some idea of the amounts and } \\
\text { ratio can give public decisions of } \\
\text { investment arbitration. }\end{array}$ \\
\hline Cost of production & $\begin{array}{l}\text { the parties shall bear all } \\
\text { technical costs of production } \\
\text { and also pay the fees of the } \\
\text { arbitrators. }\end{array}$ & $\begin{array}{l}\text { the main component of the costs } \\
\text { of the parties remains the payment } \\
\text { for the services of legal advisors, } \\
\text { which literally exceeds all other } \\
\text { costs combined. In this regard, } \\
\text { with increasing duration of the } \\
\text { arbitration proceedings, at a cost } \\
\text { they are closer to ordinary court }\end{array}$ \\
\hline
\end{tabular}

${ }^{12}$ Fedorenko N. In. Dzyuba L. M. Civil procedure. Textbook. Rostov n/d: Rostov state University, /rinel.2017-158.

${ }^{13}$ Volgograd State University, Komarova E. V. /Tver State University), Frederick SROs /Kent State University/.International commercial arbitration /Rus./. The course «international business». The project of the three universities. Retrieved 20 may 2012. 


\begin{tabular}{|c|c|c|}
\hline & & $\begin{array}{l}\text { cases. In the beginning of its } \\
\text { history, arbitration was viewed as } \\
\text { faster and less expensive form of } \\
\text { justice. C over time, this } \\
\text { advantage of arbitration is } \\
\text { increasingly questioned. }\end{array}$ \\
\hline $\begin{array}{l}\text { The duration of the } \\
\text { production. }\end{array}$ & $\begin{array}{l}\text { arbitration is conceived as a } \\
\text { shorter in comparison with the } \\
\text { proceedings in court, due to the } \\
\text { fact that the arbitration } \\
\text { decision usually cannot be } \\
\text { appealed, and because the } \\
\text { parties are no more than one } \\
\text { "instance" when considering } \\
\text { his case. }\end{array}$ & $\begin{array}{l}\text { the desire of the arbitral Tribunal } \\
\text { to take "more right" decision in } \\
\text { complex arbitration disputes, } \\
\text { leading often to the fact that } \\
\text { production takes years. It is } \\
\text { necessary, however, to understand } \\
\text { that the duration of production is } \\
\text { often caused by objective (not } \\
\text { dependent of arbitrators) reasons, } \\
\text { such as: a large volume of } \\
\text { documents, evasion of one of the } \\
\text { parties of the proceedings... }\end{array}$ \\
\hline Neutrality & $\begin{array}{l}\text { arbitration, which is conducted } \\
\text { by neutral individuals } \\
\text { (including from third countries) } \\
\text { and which decisions are } \\
\text { executed everywhere, is much } \\
\text { more preferable. }\end{array}$ & $\begin{array}{l}\text { if the parties to a contract are from } \\
\text { two different States suggest the } \\
\text { dispute between them, each of } \\
\text { them will be difficult to agree to } \\
\text { treat it in the vessels of the } \\
\text { opposite side, as it is obvious that } \\
\text { the foreign side will cause some } \\
\text { level of prejudice. At the same } \\
\text { time, the courts of a third state } \\
\text { may refuse to accept the claim to } \\
\text { consideration, and in any case } \\
\text { their decision will be difficult to } \\
\text { fulfill. }\end{array}$ \\
\hline
\end{tabular}

\subsection{Types of international commercial arbitration}

There are two types of international commercial arbitration - institutional and isolated. Institutional arbitration is a permanent body created, as a rule, at the chamber of Commerce, trade Union or Association. At the heart of its creation is the constituent document - the Charter, Statute or regulation, which determine the legal status of arbitration, its organizational structure, functioning, composition and competence. Dispute resolution procedure enshrined in the arbitration rules, which represent the rules of procedure of institutional arbitration.

Stand-alone arbitration is only to resolve the specific dispute and after the decision ceases to exist. The legal status of the isolated arbitration is entirely based on the arbitration agreement of the disputing parties themselves who determine the rules of procedure of the dispute in this arbitration. This is usually done by direct reference to existing international soft-law instruments - the Arbitration regulations of the 
UNECE 1966 and the UNCITRAL Arbitration rules 1976. In the practice of international commercial arbitration is a preference for institutional arbitration.

\subsection{Concept, types and bases of validity of international arbitration agreements}

In the basis of functioning the international commercial arbitration lies with the arbitration agreement of the disputing parties. The arbitration agreement is the parties' agreement to submit to arbitration disputes arising between the parties. The essence of the arbitration agreement is a mutually agreed expression of will of the parties to an international commercial contract.

There are two types of arbitration agreements - arbitration clause and the arbitration compromise.

The arbitration clause is a condition and fundamental part of international commercial contract because an arbitration clause included in contracts at the stage of its drafting and signing. It provides referrals to arbitration of those disputes that can only arise in the future.

The arbitration compromise or arbitration record, as a separate arbitration agreement, is distinct from the main contract and concluded by the parties after the occurrence of a particular dispute.

\section{Discussion}

Thus, because of the research the hypothesis was proved, which confirms the inevitability of the development of international commercial arbitration. Ending with analysis rules for determining the applicable law in international commercial arbitration, it is necessary to highlight the following:

$\checkmark \quad$ It is one of the most essential practice between proceedings in international commercial arbitration from litigation before national courts.

$\checkmark$ The international commercial dispute is interested in deciding primarily on the basis of the rules specifically designed to regulate this type of relations and accepted in the international commercial turnover.

$\checkmark$ While state courts are guided primarily by the provisions of national law, arbitration is always bound by the provisions of the trade practices regardless of the applicable law.

$\checkmark$ The application of the trade practices allows most adequately, thoroughly and professionally to resolve international commercial disputes.

\section{Conclusion}

It should be noted that the international Convention was adopted a long time ago with several provisions complicating the economic cycle. In this regard, there is a 
need for continuous improvement of the standards on arbitration. The lawmakers need to find new ways to arbitrage and to protect the rights of the parties in the arbitration. International economic activity is booming, so there is a need for enforcement of decisions rendered in the country other than those whose recognition is sought by enforcement.

It should also be noted that the main role in the development of the mechanism of dispute settlement in international commercial arbitration should be played by the participants of foreign economic activity, which must come to the realization that international commercial arbitration is most consistent with their interests as a way of consideration of foreign economic disputes.

The participants of foreign economic activity should be respectful to the arbitration, partners, to their promise in the arbitration agreement, and then to the efforts of the UN committees, the institutional arbitrations and other states for the development of international commercial arbitration which will bring positive results at the end.

\section{Regulations:}

1) The Civil procedure code of the Russian Federation from 14.11.2002 N 138-FZ /ed. by 29.07.2017//Rev. and EXT., joined in force 10.08.2017.

2) The Arbitration procedural code of the Russian Federation of 24.07.2002 N 95-FZ /ed. by 29.07.2017.

3) The Constitution of the Russian Federation (adopted by popular vote 12.12.1999 taking into account the amendments introduced by Laws of the Russian Federation about amendments to the Constitution of the Russian Federation from 30.12.2008 N 6-FKZ, from 30.12.2008 N 7-FCL from 05.02.2014 No. 2-FKZ, from 21.07.2014 N 11-FKZ.

4) The Convention of United Nations on the recognition and enforcement of foreign arbitral awards /Lies in the city of New York in 1958//with «Status of the Convention on the recognition and enforcement of foreign arbitral awards» (New York, 10 June 1958//as 17.05.2016.

5) European Convention on international commercial arbitration/Concluded in Geneva 21.04.1961//with Status of the European Convention on international commercial arbitration, Geneva 21 April 1961 /as 24.08.2017.

6) European Convention on the introduction of a Uniform law on arbitration /ETS N 56/ /eng., eng.//Concluded in Strasbourg 20.01.1966.

7) Inter-American Convention on international commercial arbitration /Lies in the city of Panama 30.01.1975.

8) The Law of the Russian Federation of 07.07.1993 N 5338-1 /ed. by 29.12.2015/ «On international commercial arbitration»/along with «Regulation on the International commercial arbitration court at Trading-industrial chamber of the Russian Federation», «Regulation on the Maritime Arbitration Commission at the chamber of Commerce of the Russian Federation».

9) The UNCITRAL model law «on international commercial arbitration», adopted in New York at 21.06.1985 at the 18th session of UNCITRAL. 


\section{References:}

Cordero-Moss, G. 1996. A Sight to Behold. The autonomy of the will in the practice of international commercial arbitration: Guitarcross, under the editorship of A.A. Rubanov, ROS. Acad. Sciences, Institute of state and law. Norskhydro.

Fedorenko, N. and Dzyuba L.M. 2017. Civil procedure. Textbook. Rostov State Economic University (RINH).

Getman-Pavlova, I.V. 2005. Private International law. Textbook, Moscow, Publishing house Eksmo.

Karabelnikov, B.R. 2013. International commercial arbitrable. M. Moscow School of Social and Economic Sciences.

Khlestova, K. 1980. Acting Arbitration in foreign trade relations of member countries of the CMEA. M. Nauka.

Lebedev, S.N. 1965. International commercial arbitration. An Internship Relationship. Moscow.

Minakov, A.I. 1985. Arbitration agreement and the practice of consideration of foreign economic disputes. The Faculty of Law, Moscow.

Musin, V.A., Skvortsov, O.Y. 2012. International commercial arbitration: A Tutorial. Infotropic Media, Moscow.

Nikolyukin, S.V. 2017. International civil procedure and international commercial arbitration: A textbook / S.V. Nikolyukin, Moscow, LEGAL.

Patoka, L.V. 2012. Volgograd State University, Komarova E.V. /Tver State University/, Frederick SROs /Kent State University). International commercial arbitration /Rus./. The course «international business». The project of the three universities. 